\title{
Simultaneous Determination of Low Molecule Benzotriazoles and Benzotriazole UV Stabilizers in Wastewater by Ultrasound-Assisted Emulsification Microextraction Followed by GC-MS Detection
}

Kotowska Urszula ( ukrajew@uwb.edu.pl )

University of Białystok

\section{Struk-Sokołowska Joanna}

Bialystok University of Technology

Piekutin Janina

Bialystok University of Technology

\section{Research Article}

Keywords: Benzotriazoles, Municipal wastewater, Dairy wastewater, Ultrasound-assisted emulsification microextraction, Removal efficiency, Mass loads

Posted Date: March 5th, 2021

DOI: https://doi.org/10.21203/rs.3.rs-263795/v1

License: (c) (i) This work is licensed under a Creative Commons Attribution 4.0 International License. Read Full License 


\section{Abstract}

A rapid, sensitive, economically and ecologically friendly method based on one-step ultrasound-assisted emulsification microextraction (USAEME) and in situ derivatization followed by gas chromatography-mass spectrometry (GC-MS) for simultaneous determination of low molecular benzotriazoles (LMBTs) and benzotriazolebased ultraviolet filters (BUVs) was developed. The optimized method allow quantification of benzotriazole (BT), 4methylbenzotriazole (4MBT), 5-methylbenzotriazole (5MBT); 5-chlorobenzotriazole (5CIBT), 2-(2'-hydroxy-3'-tertbutyl-5'-methylphenyl)-5-chlorobenzortriazole (UV326) and 2-(2'-hydroxy-5'-(1,1,3,3tetramethylbutyl)phenyl)benzotriazole (UV329) in municipal and industrial (dairy) wastewater. The method was validated using real influent and effluent wastewater and samples at various stages of the purification process. Obtained relative recoveries were between 77 and 137\%, limits of detection (LoDs) from 0.001 to $0.035 \mu \mathrm{g} / \mathrm{L}$, the repeatability expressed by the coefficient of variation (CV) did not exceed $12 \%$. The use of the method for the determination of the tested compounds in municipal and industrial wastewater showed their presence in most of the tested samples, in concentrations from LoD to $6.11 \mu \mathrm{g} / \mathrm{L}$. The conducted studies of samples from municipal wastewater treatment plant (WWTP) located in north-eastern Poland showed that the effectiveness of benzotriazole removal by this plant is from 29 to $84 \%$. The load of tested compounds released into the environment by this facility ranges from 2 to $269 \mathrm{mg} /$ day/1000 inhabitants.

\section{Introduction}

The presence of organic micropollutants in various elements of the environment is a major problem, as these compounds can pose a significant threat to living organisms or entire ecosystems. Its presence is caused by rapid industrial and technological development ${ }^{1}$. Benzotriazole (BT) and its derivatives are high-production-volume chemicals, and reports on their toxicity require careful assessment of their distribution in the environment ${ }^{2}$. Micropollutants from the BT group are formed as a combination of benzene and triazole particles. This structure is susceptible to a number of multiple reactions, resulting in a large number of derivatives. LMBTs are polar compounds and have good solubility in water ${ }^{3}$. The $\mathrm{pK}_{\mathrm{a}}$ values of LMBTs are between 7.9 to 9.0. A solution of LMBT has a slightly acidic reaction. They tend to be non-ionic at neutral $\mathrm{pH}^{4}$. Benzotriazole acts as an electron donor or precursor to radicals or carboanions. It is easily introduced into other chemical structures through a number of reactions such as condensation or addition ${ }^{5}$. The values of the octanol-water partition coefficient are 1.4 for BT and 1.7 for metylobenzotriazoles. Their properties also include considerable resistance to oxidation and biodegradation $^{6}$. Therefore benzotriazoles are only partialy removed by activated sludge and other treatment processes such as chlorination and advanced oxidation ${ }^{7}$.

BTs can form stable and durable complexes with metals, resulting in a protective layer on the metal surface. Anticorrosion properties have particles containing in their structure a hydrogen atom in position 1 and compounds with methyl group, especially 5MBT and 4MBT. BTs can be used as solder, brass, steel, cast iron and aluminium protection agents and are used in heating systems ${ }^{3}$. Phenyl group of benzotriazoles, especially in position 2 , absorb UV light in the wavelength range 300 to $400 \mathrm{~nm}$. There is a large group of compounds containing a benzotriazole moiety used to stabilise against UV radiation ${ }^{8}$. BUVs protect against degradation and yellowing of products. They are used in the production of paints, films, plastics, coatings and are components of skin care products ${ }^{9,10}$. BT and its derivatives are a component of detergents, including dishwasher tablets and powder. Benzotriazoles are a component of antifreeze agents and de-icing agents. Antifreeze mixtures for various surfaces (roads, airports, car parks) are now widespread and widely used. As a result, the risk of BTs entering the environment from the above 
mentioned source is very high ${ }^{11}$. BT derivatives are widely used in the pharmaceutical industry. They are also additives in petroleum products. One of the main objectives of using these compounds is to increase the efficiency and durability of products ${ }^{2}$.

The biological activity of many BT derivatives and its durability in the environment is connected with observed negative impact on the aquatic and terrestrial organisms ${ }^{12}$. These compounds are classified as hazardous to the environment and causing long-term harmful effects ${ }^{13}$. Benzotriazoles can be absorbed by inhaling the aerosol and by ingestion ${ }^{14}$. Toxicological studies have shown that benzotriazoles have mutagenic and toxic effects on some microorganisms, including algae and also plants ${ }^{15,16}$. BTs can inhibit the growth of bacteria and weaken their ability to degrade certain organic compounds, leading to impairment of the self-purification process when these compounds enter the river from a wastewater treatment plant ${ }^{4}$. The BTs have been shown to be genotoxic and may disrupt hormonal management ${ }^{17}$. BT at higher concentrations showed antagonistic interaction with the androgenic receptor and potential disruption of the thyroid hormone system and fatty acid metabolism ${ }^{18}$. It has been proven that $1 \mathrm{H}$-benzotriazole has carcinogenic properties for humans. According to Shi et al. ${ }^{4}$ benzotriazoles are associated with the development of endometrial cancer. Toxicity studies have shown that direct contact with some widely used BUVs can cause inflammation and skin irritation. Gender-related hematological and histopathological changes in the liver, kidneys, spleen and thyroid glands were observed after long-term toxicity testing of 2-(3,5-di-tert-butyl-2hydroxyphenyl) benzotriazole (UV-320) in rats. Similar properties were also shown for 2-(3,5-di-tertert-butyl-2hydroxyphenyl) benzotriazole (UV-328) ${ }^{19}$. Some BUVs were also found to have similar estrogenic effects to those shown by the natural sex hormone $17-\beta$-estradiol ${ }^{20}$.

BTs are fourt most aboundant aquatic contaminants, after ethylenediamine tetraacetic acid and its salts, nitrilotriacetic acid, and alkylbenzene sulfonates ${ }^{21}$. Their annual consumption in the United States alone exceeds 9,000 tons, it can also be presumed that it is very high in all developed economies ${ }^{22,23}$. Quantification of benzotriazoles and its derivatives in environmental samples is carried out mainly by chromatographic methods, although the literature describes the use of electrochemical and spectrophotometric methods for this purpose ${ }^{24,25}$. High-performance or ultra-high-performance liquid chromatography (HPLC, UHPLC) is usually used to determine BTs in the environmental and in biological samples. Detection is carried out using UV spectrophotometr, diode array detector (DAD), or mass spectrometer (MS) ${ }^{19,26-29}$. The greatest sensitivity and selectivity of the determinations was achieved using UHPLC with tandem MS detector of triple quadrupole (QqQ MS/MS) or electrospray ionization (ESI $\mathrm{MS} / \mathrm{MS}$ ) configuration ${ }^{30}$. Determination of highly polar low mass compounds from the group of BT derivatives by $\mathrm{GC}$ requires the use of polar stationary phases or the conversion of compounds to less polar and more volatile derivatives, for example by acetylation or methylation ${ }^{6,13,20,31-33}$. Less polar BT derivatives such as BUVSs can be analyzed by GC on standard medium polar columns without a derivatization process ${ }^{22,34}$. MSs with electron ionization (EI) and a quadrupole (Q) or a time-of-flight (ToF) analyzers as well as tandem mass spectrometers (MS/MS) were used as GC detectors. Undoubtedly, the isolation and enrichment of samples is a key step in a correct analytical procedure for the determination of trace contaminants in a complex matrix. Wastewaters contain many chemical compounds, often with similar properties, and with a large variation in composition over time. A solid phase extraction (SPE) technique is usually used to extract benzotriazoles from aqueous samples ${ }^{16,28,35}$. In recent years, microextraction techniques have become more and more important in environmental analysis, including benzotriazole analysis. Ahmad et al. described the use of bar adsorptive microextraction (BAME) to isolate BT and $5 \mathrm{MBT}$ from rain, tap, estuarine waters as well as wastewater ${ }^{29}$. Dispersive liquid-liquid microextraction (DLLME) was used for isolation of low molecule benzotriazoles in water samples ${ }^{33}$. Lu et al. proposed the use of air assisted 
liquid-liquid microextraction (AALLME) in the procedure for the determination of BT, 5MBT and 5CIBT in aqueous samples ${ }^{26}$.

The aim of presented work was the development of a simple methodology based on ultrasound assisted emulsification microextraction (USAEME) with in-situ derivatization and GC-MS for simultaneous determination four LMBTs: BT, 4MBT, 5MBT, and 5CIBT as well as two BUVs: UV 326 and UV329 in wastewater. The USAEME technique described for the first time by Requeiro et al. is isolation technique based on the emulsification of a microliter volume of organic solvent in aquous sample by ultrasound radiation and separation of both phases by centrifugation ${ }^{36}$. The literature review shows that so far USAEME has not been used for determination of BTs in any matrix, and no liquid-liquid microextraction has ever been used in the determination of the BUVs in any samples. Wastewater samples taken from municipal and industrial WWTPs collected at various stages of the technological process have been analyzed. The effectiveness of the BTs removal processes in individual tested unit as well as its mass loads was also determined.

\section{Results And Discussion}

\section{Optimization of the extraction and derivatization procedure}

Very few procedures for the determination of benzotriazoles by GC in combination with single quadrupole MS have been published $23,31,33,35,37$. Based on previous literature reports, an acetylation reaction was selected for the derivatization of BTs in this work, which was carried out simultaneously with the extraction process. A careful impact analysis has been carried out for the following process conditions: the type and volume of the extraction solvent, the volume of acetic anhydride (derivatization reagent), the addition of a buffer salt and the time of simultaneous extraction and derivatization. $n$-Hexadecane, 1-undecanol, chloroform, carbon tetrachloride, toluene and chlorobenzene were tested as potential extraction solvents. The characteristics of selected solvents are included in Table S1 (Supplementary Material). The responses obtained for each analyzed compound when different solvents were used for extraction are shown in Fig. 1A. The volume of each of the solvents used for the extraction was 100 $\mu \mathrm{L}$. Optimization was performed for milli-Q water to which a mixture of analytes was introduced, with a concentration of $10 \mu \mathrm{g} / \mathrm{L}$ each. Other conditions of the process were as follows: $100 \mu \mathrm{L}$ of acetic anhydride, five minutes extraction time. The same conditions were used in all optimization experiments unless otherwise stated.

Chlorinated solvents with a density greater than that of water were selected for the tests (see Table S1, Supplementary Material), enabling easy removal of the organic layer after extraction by using test tubes with a conical bottom ${ }^{36}$. $n$-Hexadecane and 1-undecanol make it possible to separate from the aqueous solution after extraction by solidifying a floating solvent drop, due to the corresponding melting points, which are $18^{\circ} \mathrm{C}$ and $13^{\circ} \mathrm{C}$, respectively ${ }^{38}$. Aromatic solvents were selected due to their structural similarity to analytes and the possibility of forming $\pi-\pi$ interactions, which may positively affect the extraction efficiency ${ }^{33}$. As expected, the highest extraction efficiency was achieved with the use of chlorobenzene and toluene, while the area of the chromatographic peaks recorded when the extractant was chlorobenzene was 13 to $22 \%$ higher than in the case of toluene. It can also be seen that for chlorobenzene, the lowest standard deviations of the recorded peak areas were recorded. When making the selection, the toxicity of solvents was also taken into account, which was against the chlorobenzene. In contrast, the toxicity of chlorobenzene is lower than that of other organochlorine solvents used in microextraction techniques. The use of toluene as the extractant requires additional operations to separate it from the extracted matrix. Moving to other vessels for this purpose is associated with the risk of losing some of the solvent or recontaminating the sample. At the same time, all additional operations increase the exposure of the analyst and the environment to the 
contact with the solvent. Taking all the above into account, chlorobenzene was selected as the optimal solvent for the extraction.

Optimal solvent volume was selected on the basis of tests performed at 40,60 and $80 \mu \mathrm{L}$. The results of the conducted experiments are presented in Fig. 1B. As expected, there was clearly an inverse relationship between the volume of the solvent and the area of the obtained analyte peaks. Therefore, it was found that the volume of $40 \mu \mathrm{L}$ is optimal for the conducted experiments. The solubility of chlorobenzene in water is approximately $500 \mathrm{mg} / \mathrm{L}$, so the theoretical amount of solvent that can be recovered after extracting a $5 \mathrm{~mL}$ water sample is $37.5 \mu \mathrm{L}$. After extraction, it was possible to collect about $25 \mu \mathrm{L}$ of chlorobenzene, which made it possible to carry out several replications of the analysis using the autosampler of the GC-MS device. In order to make sure that the determined optimal volume could be used during the wastewater analysis, additional experiments were carried out using influents as well as the wastewater from different treatment stages. For influents, it was found necessary to use a solvent volume of $80 \mu \mathrm{L}$ to obtain $15-20 \mu \mathrm{L}$ of extract that could be analyzed by GC-MS. It is related to the presence of a rich matrix in wastewater, including macromolecular compounds (proteins, fats and carbohydrates), i.e. substances with emulsifying properties, increasing the solubility of chlorobenzene ${ }^{39}$. Therefore, it was decided to use a volume of solvent equal to $80 \mu \mathrm{L}$ in all subsequent experiments. However, when the developed method will be used for samples of less polluted water, including surface water, groundwater, and purified sewage, it is possible to use a chlorobenzene volume of $40 \mu \mathrm{L}$.

The optimization results for acetic anhydride volume, ionic strength and extraction time are shown in Fig. 2. The effect of acetic anhydride volume on the extraction efficiency was investigated in the range from 60 to $250 \mu \mathrm{L}$ and $125 \mu \mathrm{L}$ was selected as optimal. It turned out to be sufficient also when the experiments were repeated with samples of raw sewage enriched with analytes at a concentration of $100 \mu \mathrm{g} / \mathrm{L}$.

Many studies have been carried out and described in the literature on the selection of the appropriate salt or buffer solution for liquid-liquid microextraction ${ }^{36,40}$. As a result, it was found that the optimal choice in this case are phosphoric $(V)$ acid salts with buffering properties. In microextraction methods, especially in USAEME, the use of sodium bicarbonate is disadvantageous because the formation of $\mathrm{CO}_{2}$ bubbles makes it difficult to separate the extract from the aqueous matrix ${ }^{41}$. However, the influence of the ionic strength on the process of benzotriazole microextraction is unclear, as the available literature gives completely opposite findings ${ }^{26,33}$. In this study, the effect of salt addition ranging from 0 to $10 \%$ was investigated. The obtained results do not show an unequivocal relationship between the obtained analyte peak areas and salt concentration. Similar results were obtained for concentrations of $0,2.5$ and $5 \%$. In the case of concentrations of 7.5 and $10 \%$, higher peak areas were obtained for BT and $4 \mathrm{MBT}$, and lower for $5 \mathrm{MBT}$. In order to definitively settle this issue, the research was repeated for 0 and $10 \%$ concentrations with the use of influent wastewater with addition of benzotriazoles. Studies have shown that in the case of a very complex matrix, which is untreated wastewater, the addition of buffering salt causes precipitation during extraction, which makes it difficult to take the appropriate volume of extract. Therefore, in further works, no salt was added to the extracted matrix. A similar solution was selected as optimal also when using the DLLME technique ${ }^{33}$.

The relationship between the time of simultaneous extraction and derivatization, and the extraction efficiency was studied in the range of three to 12 minutes. Extending the simultaneous extraction and derivatization time from 3 to 5 minutes results in an increase in surface areas by about $10 \%$. The surface areas obtained after 12 minutes of the process, for all tested compounds, were about $30 \%$ lower than those obtained after 5 minutes. The decrease in analyte surface areas with the extension of sonication time indicates that acetyl derivatives of benzotriazoles are 
likely to partially hydrolyze to free forms upon prolonged contact with the aqueous phase. This phenomenon has already been observed in the case of other polar compounds ${ }^{38}$.

\section{Method validation}

Analytical parameters including linearity, precission, LoD, and limit of quantification (LoQ) as well as method recovery were investigated under established optimal conditions. Calibration curves were obtained by spiking the ultrapure water with seven concentration levels, between 0.05 and $10 \mu \mathrm{g} / \mathrm{L}$ and performing the extraction and GC-MS analysis. In the case of 5CIBT two chromatographic peaks were recorded. This situation is probably related to the formation of two isomeric acetyl derivatives of $5 \mathrm{CIBT}$, substituted at the 1 and 3 positions of the triazole ring ${ }^{42}$. Calibration curves for this compound were plotted and validation parameters were determined based on peak 1 , peak 2 and the sum of the peaks. The validation data are summarized in Table 1. Calibration curves were linear within the studied concentration ranges with coefficients of determination $\left(r^{2}\right) \geq 0.9900$ for all target compounds.

The LoD was established as the concentration giving a signal-to-noise ratio ( $\mathrm{S} / \mathrm{N}$ ratio) of 3 and it was measured in chromatograms registered for the solutions with lowest analytes concentration. The LoQ was calculated as the concentration corresponding to an S/N ratio of 10 . LoDs and LoQs values for the tested benzotriazoles ranged from 0.1 to $1.8 \mathrm{ng} / \mathrm{L}$ and from 0.4 to $5.9 \mathrm{ng} / \mathrm{L}$, respectively. The lowest detection and quantification limits were recorded for UV326, UV329 and 5MBT.

The precision of the determinations was established on the basis of CV calculated for developed model (calibration curve). The CV for each point was calculated as the ratio of the root mean squared error to the mean of the concentration calculated on the basis of the model ${ }^{43}$. The CV given in Table 1 was calculated as the average percent value of the variance coefficients determined for seven points of the calibration curves. For the individual compounds tested, mean CV values ranging from 4.7 to $9.8 \%$ were obtained. As expected, the measurements for higher concentrations are characterized by the highest precision. The mean CV value for all tested compounds at a concentration of $10 \mu \mathrm{g} / \mathrm{L}$ was $4.7 \%$, while for the concentration of $0.05 \mu \mathrm{g} / \mathrm{L}$ it was almost $15 \%$. Recoveries for each compound were determined at two concentration levels: 0.2 and $2 \mu \mathrm{g} / \mathrm{L}$. They were calculated comparing nominal concentration with the value determined based on the calibration curve. The recovery values were between 81 and $116 \%$ for the lower concentration, and between 87 1nd 118\% for the higher value.

\section{Matrix effect}

Municipal and industrial wastewater are water matrices with a high degree of pollution and properties strongly differing from those of pure water. A complicated matrix may affect the surface area of the obtained analytical signals as well as the location and course of the baseline. It is assumed that the influence of the matrix at the level of -20 to $20 \%$ is considered acceptable and determinations can be made on the basis of a calibration performed on a simplified matrix. With stronger disturbances, matrix-matched calibration must be used ${ }^{44}$. The tests of the resistance of the method showed that the discrepancies of the received signals exceed the determined range. The highest exceedances were recorded when the matrix was influents. Therefore, the developed method was validated with the use of six different real matrices (see Table S2 and Table S3, Supplementary Material). For all municipal wastewater matrix, good linearity was obtained, expressed as $r^{2}$ value above 0.99 . The mean recovery deviation from the value of $100 \%$ was the highest for influent wastewater and was approximately $18 \%$. In the case of the remaining matrices, it ranged from 8 to $13 \%$, i.e. it did not differ significantly from the values determined for water. The CV values did not exceed $10 \%$. It was probably influenced by the higher concentrations within the curve. The average sensitivity of determinations for the group of the target compounds, expressed by the LoD value, in the case 
of municipal wastewater as matrices, ranged from 6 to $14 \mathrm{ng} / \mathrm{L}$. In the case of industrial wastewater as a sample matrix, the deviation of validation parameters from those registered for water is higher than in the case of municipal wastewater. In this case, average values of the difference in recovery from $100 \%$ equals $25 \%$ for influents and $12 \%$ for wastewater after flotation. Higher values of CV, and LoD were also recorded. It can be seen that the deterioration of the recovery and the reduction of sensitivity, is quite well correlated with the contamination of the matrix used, expressed by the BOD, COD, suspension, nitrogen and phosphorus concentrations (see Tables S4, S5, S6 Supplementary material).

\section{Comparison with other analytical procedures}

Due to its high polarity and limited volatility, liquid chromatography is the most commonly used in BTs analysis, usually combined with MS or MS/MS detection. The limited availability of this type of equipment as well as the high cost of determinations and large production of waste solvents are significant obstacles of LC-MS/MS technique. GCMS systems, especially those with one quadrupole, are currently common equipment in laboratories conducting environmental determinations. At the same time, GC-MS analyzes are cost-friendly, easy to perform and environmentally friendly due to the small amount of waste generated. The development of derivatization in the matrix in recent years facilitated the use of GC in the analysis of compounds even with high polarity. Table 2 presents a comparison of the developed method with other solutions used in the determination of BTs. Due to the fact that in the literature from recent years there are comparisons of BTs determination methods, only procedures based on gas chromatography and various isolation techniques were taken into account ${ }^{22,26,29}$. Comparing the developed procedure with others described in the literature, it can be stated that the validation parameters determined by us are similar or better than in the case of other determinations performed with the GC-MS and GCMS/MS techniques. The comparison of isolation techniques shows that SPE, DLLME and USAEME allow determinations with similar accuracy, precision and sensitivity, while the use of SPME is associated with the deterioration of the validation parameters of the procedure. It should be emphasized, however, that the procedures based on the use of SPE are multi-stage (conditioning of columns, sample application, elution, concentration of the eluate) and require a large volume of samples (even $2.5 \mathrm{~L}$, on average $1 \mathrm{~L}$ ) and the use of large volumes of organic solvents (up to $61 \mathrm{~mL}$ per one repetition of the procedure) ${ }^{23}$. These facts justify the growing popularity of liquidliquid microextraction techniques. The DLLME-GC-MS and USAEME-GC-MS procedures have similar analytical characteristics (with a slight advantage of the first technique), while the 20 times higher consumption of organic solvents in the DLLME technique (sum of the extraction and dispersion solvent volumes) should be considered as an advantage of USAEME. A significant improvement of the proposed method, compared to the DLLME-based procedure, is the simple, one-step recovery of the solvent after extraction, which is associated with a lower risk of sample contamination and analyte loss ${ }^{33}$.

\section{Wastewater analysis}

The developed USAEME-GC-MS procedure was used for the simultaneous determination of compounds from the LMBT and BUV groups in wastewater from two municipal wastewater treatment plants and in the outflow of MPP. Fig. 3 show chromatograms recorded for the influent and effluent wastewater from WWTP A. Table 3 summarizes the concentrations of the target LMBTs and BUVs in samples of municipal wastewater from WWTP A and WWTP B and in dairy wastewater from MPP. BT, $4 M B T$ and $5 M B T$ determinations were performed on six samples of municipal influents and six samples of effluents (five from WWTP A and one from WWTP B). 5CIBT, UV326, and UV329 determinations were carried out in four samples of each type from WWTP A. Average concentrations of LMBTs in influent wastewater, along with deviations, ranged from $0.055 \pm 0.007 \mu \mathrm{g} / \mathrm{L}$ for $5 \mathrm{ClBT}(\mathrm{N}=2$, two values

Page $7 / 22$ 
below the LOD) to $2.205 \pm 2.335 \mu \mathrm{g} / \mathrm{L}$ for BT. Among the methyl derivatives of $\mathrm{BT}$, the higher concentration of $1.117 \pm 2.058 \mu \mathrm{g} / \mathrm{L}$ was recorded for $4 \mathrm{MBT}$ and for $5 \mathrm{MBT}$ it was $0.158 \pm 0.136 \mu \mathrm{g} / \mathrm{L}$. For BUVs, the mean concentrations in municipal influents were $0.190 \pm 0.082 \mu \mathrm{g} / \mathrm{L}$ and $0.167 \pm 0.038 \mu \mathrm{g} / \mathrm{L}$ for UV326 and UV329, respectively ( $N=3$, one value below LOD). In the treated wastewater, the average concentrations of $B T(N=6), 4 M B T$ $(\mathrm{N}=6), 5 \mathrm{MBT}(\mathrm{N}=4)$ and $5 \mathrm{ClBT}(\mathrm{N}=2)$ were $1.065 \pm 0.907 \mu \mathrm{g} / \mathrm{L}, 0.150 \pm 0.171 \mu \mathrm{g} / \mathrm{L}, 0.178 \pm 0.215 \mu \mathrm{g} / \mathrm{L}$, and $0.010 \mu \mathrm{g} / \mathrm{L}$, respectively. The mean concentrations of UV326 $(\mathrm{N}=3)$ and UV329 $(\mathrm{N}=2)$ were $0.040 \pm 0.036 \mu \mathrm{g} / \mathrm{L}$ and $0.050 \pm 0.028$ $\mu \mathrm{g} / \mathrm{L}$, respectively. The LMBTs content in municipal influents determined in this study is similar to the values obtained during the research conducted in Spain by Dominguez et al. ${ }^{31}$. Other results that can be found in the literature indicate a higher content of these compounds, reaching $13 \mu \mathrm{g} / \mathrm{L}$ for BT and over $7 \mu \mathrm{g} / \mathrm{L}$ for other LMBTs $^{22,45,46}$. The content of LMBTs in municipal effluents similar to that recorded by us was obtained by Liu et al. and Casado et al. for samples from Australia and Spain $22,33,34$. The remaining literature reports give higher concentrations of these compounds in effluents, reaching $10 \mu \mathrm{g} / \mathrm{L}^{45}$. The content of BUVs in municipal influents reported in the literature is over ten times higher than the values recorded by $u^{34}$.

Fig. 4 shows the range and mean ML of target compounds flowing with influents into WWTP A and introduced with effluents from WWTP A into the aquatic environment. Fig. 5 shows the range and average values of the removal efficiency (RE) of individual compounds in the WWTP A. When no compound was detected in a specific matrix, the appropriate LOD value was inserted into the calculation of $\mathrm{ML}$ and $\mathrm{RE}$. The $\mathrm{ML}$ values for each target compound was estimated according to Eq. (1). The average ML values calculated for influents ranged from approximately 8 $\mathrm{mg} /$ day/1000 inhabitants for 5CIBT to almost $600 \mathrm{mg} /$ day/1000 inhabitants for BT. For the remaining compounds, these values were at the level of several dozen $\mathrm{mg} / \mathrm{day} / 1000$. The lowest mass load introduced into the environment was recorded for 5 CIBT and it was $2.2 \mathrm{mg} /$ day/1000 inhabitants. $269 \mathrm{mg} /$ day/1000 inhabitants was the ML for BT, which was the highest recorded value. The average $M L$ value for the remaining compounds ranged from a few to several mg/day/1000 inhabitants.

Efficiency (RE, \%) of the removal of LMBTs and BUVs during the treatment process depends on its tendency to be absorbed by activated sludge as well as its biodegradability and physiochemical properties (volatility, polarity, water solubility). RE is defined as negative or low when $\mathrm{RE}<20 \%$, moderate when the RE ranged between $20.1 \%$ and $70 \%$ and high when the RE exceeded $70.1 \% 47$. As shown in Fig. 5 , the average RE value obtained for target compounds allows the removal efficiency of BT, $4 \mathrm{MBT}$ and $5 \mathrm{MBT}$ to be classified as moderate and 5CIBT, UV326, and UV329 as high. In the case of $B T, 4 M B T, 5 M B T$, in some sampling campaigns higher concentrations were observed in effluents than in influents, i.e. RE values below zero were obtained. "Negative removal" has been previously observed and it could be explained by the varying sorption of the target compounds in activated sludge and their subsequent desorption by successive portions of wastewater ${ }^{48}$. The reason may also be the fact that the influents and effluents were collected at the same time, while the treatment process in WWTP A takes about 48 hours, so the effluents come from a completely different portion of influents than taken on a given day ${ }^{49}$. On the basis of the obtained results it can be concluded that the removal of BTs by activated sludge processes is not sufficient and it is advisable to use additional technologies as the tertiary wastewater treatment.

\section{Methods}

\section{Chemicals and solutions}

Analytes: BT, 4MBT, 5MBT on the purity of analytical standards were purchased from Supelco, Germany, and 5ClBT, UV326 and UV329 of the purity not less than 99\% was obtained from Sigma-Aldrich, Germany. Most solvents: 
methanol, chloroform, carbon tetrachloride, acetone, chlorobenzene, toluene as well as anhydrous disodium hydrogen phosphate $(\mathrm{V})$ (buffering salt) were purchased from $\mathrm{POCH}$ (Poland). Acetic anhydride $(\mathrm{V})$ were provided by Chempur (Poland). Other solvents: 1-undecanol and $n$-hexadecane were obtained from Sigma-Aldrich, Germany. The standards were individually dissolved in methanol to obtain concentrations at $1 \mathrm{mg} / \mathrm{mL}$. So prepared stock solutions were stored at $-20^{\circ} \mathrm{C}$ not longer than two weeks. Working solutions were prepared by diluting the stock standard solution in methanol and stored at $-20{ }^{\circ} \mathrm{C}$ not longer than for two weeks. Deionized water was obtained using a purification system (Milli-Q RG, Millipore, USA) and was stored in glass bottles.

\section{Wastewater samples}

Average daily municipal wastewater samples were obtained from municipal wastewater treatment plants (WWTP) located in two cities in the north-east Poland. Treatment processes used by WWTPs include mechanical purification (such as grates, sieves, sand traps, settling tanks and grease separators) as well as biological purification through the use of activated sludge with no tertiary treatment. After the completion of treatment processes effluents are discharged into local rivers belonging to the catchment area of the Vistula River which is a part of the Baltic Sea drainage basin. The WWTP A is located in the city with a population of 300,000 . Daily capacity of the WWTP A equals $100,000 \mathrm{~m}^{3} /$ day. It's average processing is approximately $70.000 \mathrm{~m}^{3} /$ day. The work of the plant is based on active sludge technology (flow system) assuming the load of $\mathrm{BOD}_{5}$ equal to $30.000 \mathrm{~kg} \mathrm{O}_{2} /$ day, suspension load of $55,000 \mathrm{~kg} / \mathrm{day}$, total Kjeldahl nitrogen $6,000 \mathrm{~kg} /$ day, and total phosphorus $850 \mathrm{~kg} /$ day. Treatment efficiency meets the effluent standards required by Polish legislation for a plant of this size. Average parameters of raw wastewater are: COD $690.0 \mathrm{mgO}_{2} / \mathrm{L}, \mathrm{pH} 6.8$, total suspended solids (TSS) $460.0 \mathrm{mg} / \mathrm{L}$, total nitrogen (TN) $89.5 \mathrm{mg} / \mathrm{L}$, total phosphorus (TP) $11.9 \mathrm{mg} / \mathrm{L}^{50}$. The WWTP B is located in north-eastern Poland. It purifies wastewater from 21.000 inhabitants. It processes approximately $5,000 \mathrm{~m}^{3}$ daily. Theoretical capacity of WWTP B equals $6,600 \mathrm{~m}^{3} / \mathrm{day}$. The main source of contamination affecting the drains is municipal and industrial (dairy, charcoal and briquette production, bio-fuels). Treatment efficiency meets the effluent standards required by Polish legislation for a plant of this size. Treatment processes used by WWTPs include mechanical purification as well as biological purification through the use of activated sludge in sequential batch reactors (SBR). Average parameters of raw wastewater are: COD $1,079 \mathrm{mgO}_{2} / \mathrm{L}, \mathrm{pH}$ 6.9, TSS $430.0 \mathrm{mg} / \mathrm{L}$, TN $71.0 \mathrm{mg} / \mathrm{L}$, and TP $11.8 \mathrm{mg} / \mathrm{L}^{51}$. Considered Milk Processing Plant (MPP) belongs to the largest Polish Dairy Cooperative, which is one of the twenty largest dairy processors in Europe $^{52}$. It processes 54 million liters of milk per year. The MPP discharges dairy wastewater to the municipal WWTP after the pretreatment process. The average daily amount of dairy wastewater is $430 \mathrm{~m}^{3} /$ day, which is about $13 \%$ of the total volume of wastewater flowing into the WWTP. In terms of BOD $_{5}$ and COD load dairy sewage has $7 \%$ share in the pollution load ${ }^{53}$. Wastewater samples were gathered through the use of glass samplers, placed into glass bottles and then transported to the laboratory. Obtained samples were filtered through a $0.45 \mu \mathrm{m}$ pore membrane filter and fixed with concentrated $\mathrm{HCl}$ to $\mathrm{pH}=2$. Samples were then stored in a freezer at $-20{ }^{\circ} \mathrm{C}$. $\mathrm{pH}$ and electrolytic conductivity (EC) in municipal and dairy wastewater were measured directly using probe of Hach HQd Meter and IntelliCAL Smartprobes type, Germany. Analyses of $\mathrm{BOD}_{5}$; $\mathrm{COD}$; orthophosphates; TP; ammonia nitrogen; nitrates; TN; TSS were carried out in accordance with $\mathrm{APHA}^{54}$.

\section{The procedure of benzotriazole microextraction with in situ derivatization}

For the simultaneous extraction and derivatization of BT, 4MBT, 5MBT, 5CIBT, UV326, and UV329 an aliquots of 5 $\mathrm{mL}$ of examined liquid sample was placed in $10-\mathrm{mL}$ glass centrifuge test-tube. The extraction solvent (chlorobenzene, $80 \mu \mathrm{L}$ ) and the derivatization reagent (acetic anhydride, $120 \mu \mathrm{L}$ ) were added to such prepared 
samples and mixed. Then, tubes were immersed in an ultrasonic bath (Polsonic, Sonic-3, Poland). Extractions were performed at $42 \mathrm{kHz}$ of ultrasound frequency and $230 \mathrm{~W}$ of power for the duration of $5 \mathrm{~min}$ at the room temperature. Emulsions were disrupted by centrifugation at $6000 \mathrm{rpm}$ for $5 \mathrm{~min}$ in an MPW-250 Med. Instruments (Poland) laboratory centrifuge. The organic phase was settled at the bottom of the conical tube, which was removed using a $100 \mu \mathrm{L}$ Hamilton syringe (USA) and transferred into chromatographic vial with a $150 \mu \mathrm{L}$ insert.

\section{GC-MS conditions}

Analysis was performed with a HP 6890 gas chromatograph with a mass spectrometric detector MSD5973 and HP 7673 autosampler (Agilent Technologies, USA). This device was equipped with HP-5MS column ( $5 \%$ phenylmethylsiloxane) size $30 \mathrm{~m}$ length $\times 0.25 \mathrm{~mm}$ with $0.25 \mu \mathrm{m}$ film thickness and split/splitless injector. The injector worked in splitless mode, injection volume was $1 \mu \mathrm{L}$. Helium of purity $99.999 \%$ was used as carrier gas at flow rate $1 \mathrm{~mL} / \mathrm{min}$. The injector temperature was $250^{\circ} \mathrm{C}$. The oven temperature was programmed from $80^{\circ} \mathrm{C}$, increased at $10^{\circ} \mathrm{C} / \mathrm{min}$ to $180^{\circ} \mathrm{C}$ and $20^{\circ} \mathrm{C} / \mathrm{min}$ to $280^{\circ} \mathrm{C}$. The total run time was 17.00 minutes, the retention times were as follows: $8.00 \mathrm{~min}(\mathrm{BT}), 9.16 \mathrm{~min}(4 \mathrm{MBT}), 9.46 \mathrm{~min}$ (5MBT), $9.85 \mathrm{~min}$ and $9.91 \mathrm{~min}$ (5CIBT), $15.99 \mathrm{~min}$ (UV326), $16.46 \mathrm{~min}$ (UV329). The electron impact source temperature was $230^{\circ} \mathrm{C}$ with electron energy of $70 \mathrm{eV}$. The quadrupole temperature was $150^{\circ} \mathrm{C}$, and the $\mathrm{GC}$ interface temperature was $280^{\circ} \mathrm{C}$. The MS detector worked in Selected lon Monitoring (SIM) mode. The SIM chromatogram of the mili-Q water spiked with mixture of target compounds (100 $\mathrm{\mu g} / \mathrm{L}$ each) is presented in Figure S1 (Supplementary Material). Registered El-MS spectra of analytes are presented in Figure S2 (Supplementary Material). All signals were well separated. Single, good shape, and repeatable peaks for acetyl derivatives of BT, 4MBT, 5MBT, UV329 were obtained. UV326 did not undergo an acylation reaction due to a steric hindrance that prevented the derivatization reagent from accessing the $\mathrm{OH}$ group (see Figure S2, Supplementary Material). The chromatographic and mass spectrometric parameters together with some charasteristics and structures of target compounds are included in Table S7 (Supplementary Material).

\section{Calculation of mass loads}

Mass loads $(M L)$ were calculated by multiplying concentrations of each target compound found in wastewater samples $(C, \mu \mathrm{g} / \mathrm{L})$ the average daily flow rate $\left(Q, \mathrm{~m}^{3} /\right.$ day $)$ of the tasted plant and the population served by the WWTP $(P)$. ML values were normalized using the community equivalent (1000) according to Eq. (1) and they were expressed in $\mathrm{mg} /$ day/1000 inhabitants.

$$
M L_{i}=\frac{C_{i} \times Q \times 1000}{P}
$$

The $M L$ values of BTs flowing into WWTP A along with influents and the $M L$ values of BTs introduced into the environment along with treated wastewater were determined.

\section{Quality assurance}

Apparatus (GC-MS) and procedural blanks were registered before analysis of samples or standards, and several times during analysis cycle to check no carry-over effect and purity of reagents and equipment used. Brand new test tubes and only glass materials were applied in experiments to avoid possible bacground contamination and losses of analytes by sorption on plastic. Concentrations of studied compounds in all influent and effluent samples they were calculated on the basis of the calibration curves registered in analyzed matrix. The determinations in the wastewater collected from the nitrification chamber and from SBR were performed based on the curves recorded for 
effluents. Determinations in wastewater collected from retention chamber (after mechanical tratment) were done on the basis of calibration on influents.

\section{Declarations}

\section{Funding}

The research was supported by the Minister of Science and Higher Education (project No. WZ/WBilŚ/8/2019 of the Technical University of Bialystok) and by the Polish National Centre of Science by grant 2019/03/X/ST10/01959.

\section{Author contributions}

Conceptualization: U.K., J.S.-S., J.P. Methodology: U.K. Investigation: U.K., J.S.-S., J.P. Data Curation: U.K. Writing Original Draft: U.K., J.S.-S. Writing - Review \& Editing U.K., J.S.-S. Funding acquisition U.K., J.S.-S., J.P. All authors reviewed and approved the manuscript.

\section{Competing interests}

The authors declare no competing interests.

\section{Additional information}

Correspondence and requests for materials should be addressed to U.K.

\section{References}

1. Żyłka, R., Dąbrowski, W. \& Karolinczak, B. Modeling of electric energy consumption during dairy wastewater treatment plant operation. Energies. 13, 3769 (2020).

2. Asimakopoulos, A. G., Wang, L., Thomaidis, N. S. \& Kannan, K. Benzotriazoles and benzothiazoles in human urine from several countries: A perspective on occurrence, biotransformation, and human exposure. Environ. Int. 59, 274-281 (2013).

3. Santiago, M. R. Treatment of dairy wastewater by oxygen injection: occurrence and removal efficiency of a benzotriazole based anticorrosive. Water. 10, 155-168 (2018).

4. Shi, Z. Q., Liu, Y. S., Xiong, Q., Cai, W. W. \& Ying, G. G. Occurrence, toxicity and transformation of six typical benzotriazoles in the environment, A review. Sci. Total Environ. 661, 407-421 (2019).

5. Briguglio, I. et al. Benzotriazole: An overview on its versatile biological behavior. Eur. J. Med. Chem. 97, 612-648 (2015).

6. Matamoros, V., Jover, E. \& Bayona, J. M. Occurrence and fate of benzothiazoles and benzotriazoles in constructed wetlands. Water Sci. Technol. 61, 191-198 (2010).

7. Reemtsma, T. H., Miehe, U., Duennbier, U. \& Jekel, M. Polar pollutants in municipal wastewater and the water cycle: occurrence and removal of benzotriazoles. Water Res. 44, 596-604 (2010).

8. Cantwell, M. G., Sullivan, J. C. \& Burgess, R. M. Benzotriazoles: history, environmental distribution, and potential ecological effects. Compr. Anal. Chem. 67, 513-545 (2015).

9. Montesdeoca-Esponda, S., del Toro-Moreno, A., Sosa-Ferrera, Z. \& Santana-Rodríguez, J. J. Development of a sensitive determination method for benzotriazole UV stabilizers in environmental water samples with stir bar 
sorption extraction and liquid desorption prior to ultra-high performance liquid chromatography with tandem mass spectrometry. J. Sep. Sci. 36, 2168-2175 (2013).

10. Lai, H. J. et al. Occurrence and dissipation of benzotriazoles and benzotriazoli ultraviolet stabilizers in biosolidamended soils. Environ. Toxicol. Chem. 33, 761-767 (2014).

11. Rhodes-Dicker, L. \& Passeport, E. Effects of cold-climate environmental factors temperature and salinity on benzotriazole adsorption and desorption in bioretention cells. Ecol. Eng. 127, 58-65 (2019).

12. Lempart, A., Kudlek, E. \& Dudziak, M. Determination of micropollutants in solid and liquid samples from swimming pool systems. Proc. of the 2nd Int. Elect. Conf. Water Sci. 16-30 Nov 2017; Sciforum Electronic Conference Series, Vol. 2.

13. Corsi, S. R., Harwell, G. R., Geis, S. W. \& Bergman, D. Impacts of aircraft deicer and anti-icer runoff on receiving waters from Dallas/Fort Worth International Airport, Texas, U.S.A. Environ. Toxicol. Chem. 25, 2890-2900 (2006).

14. Suma, B. V., Natesh, N. N. \& Madhavan, V. Benzotriazole in medicinal chemistry: An overview. J. Chem. Pharm. Res. 3, 375-381 (2011).

15. Roshani, B., McMasterb, I., Rezaeib, E. \& Soltan, J. Catalytic ozonation of benzotriazole over alumina supported transition metal oxide catalysts in water. Sep. Purif. Technol. 135, 158-164 (2014).

16. Mazioti, A., Stasinakis, A., Gatidou, G., Thomaidis, N. \& Andersen, H. Sorption and biodegradation of selected benzotriazoles and hydroxybenzothiazole in activated sludge and estimation of their fate during wastewater treatment. Chemosphere. 131, 117-123 (2015).

17. Tangtian, H., Liang, B., Liu, W., Shin, P. \& Wu, R. Estrogenic potential of benzotriazole on marine medaka (Oryzias melastigma). Ecotoxicol. Environ. Saf. 80, 327-332 (2012).

18. Fent, K., Chew, G., Li, J. \& Gomez, E. Benzotriazole UV-stabilizers and benzotriazole: Antiandrogenic activity in vitro and activation of aryl hydrocarbon receptor pathway in zebrafish eleuthero-embryos. Sci. Total Environ. 482-483, 125-136 (2014).

19. Liu, R. et al. Determination of nine benzotriazole UV stabilizers in environmental watersamples by automated on-line solid phase extraction coupled with high-performance liquid chromatography-tandem mass spectrometry. Talanta. 120, 158-166 (2014).

20. Molins-Delgado, D., Távora, J., Díaz-Cruz, M. S. \& Barceló, D. UV filters and benzotriazoles in urban aquatic ecosystems: The footprint of daily use products. Sci. Total Environ. 601-602, 975-986 (2017).

21. Giger, W. Eawag research(Swiss Federal Institute of Aquatic Science and Technology, 2006).

22. Liu, Y. S., Ying, G. G., Shareef, A. \& Kookana, R. S. Simultaneous determination of benzotriazoles and ultraviolet filters in ground water, effluent and biosolid samples using gas chromatography-tandem mass spectrometry. J. Chromatogr. A. 1218, 5328-5335 (2011).

23. Sulej, A. M., Polkowska, Å., Astel, A. \& Namieśnik, J. Analytical procedures for the determination of fuel combustion products, anti-corrosive compounds, and de-icing compounds in airport runoff water samples. Talanta 117, 158 - 67(2013).

24. Ababneh, A. N., Abu-Dalo, M. A., Horn, C. \& Hernandez, M. T. Polarographic determination of benzotriazoles and their sorption behavior on granular activated carbon. Int. J. Environ. Sci. Technol. 16, 833-842 (2019).

25. Esmaile, N., Shabaneh, S., Mofavvaz, S., Sohrabi, M. R. \& Torabi, B. Spectrophotometric Determination of Trace Amounts of Benzotriazole in Aqueous Solutions Using Gold Nanoparticles: Artificial Neural Network Modeling. ChemistrySelect 5, 5712(2020). 
26. Lu, J., Wang, M. M., Wang, Q., Li, H. P. \& Yang, Z. G. Determination of benzotriazole and its derivatives in aqueous sample with air-assisted liquid-liquid microextraction followed by high-performance liquid chromatography. Chinese J. Anal. Chem. 46, e1817-e1825 (2018).

27. Lu, Z. at al. Occurrence of substituted diphenylamine antioxidants and benzotriazole UV stabilizers in Arctic seabirds and seals. Sci. Total Environ. 663, 950-957 (2019).

28. Gatidou, G., Anastopoulou, P., Aloupi, M. \& Stasinakis, A. S. Growth inhibition and fate of benzotriazoles in Chlorella sorokiniana cultures. Sci. Total Environ. 663, 580-586 (2019).

29. Ahmad, S. M., Calado, B. B., Oliveira, M. N., Neng, N. R. \& Nogueira, J. Bar adsorptive microextraction coated with carbon-based phase mixtures for performance-enhancement to monitor selected benzotriazoles, benzothiazoles, and benzenesulfonamides in environmental water matrices. Molecules. 25, 2133 (2020).

30. Pacheco-Juárez, J., Montesdeoca-Esponda, M., Torres-Padrón, M. E., Sosa-Ferrera, Z. \& Santana-Rodríguez, J. J. Analysis and occurrence of benzotriazole ultraviolet stabilisers in different species of seaweed. Chemosphere. 236, 124344 (2019).

31. Domínguez, C., Reyes-Contreras, C. \& Bayona, J. M. Determination of benzothiazoles and benzotriazoles by using ionic liquid stationary phases in gas chromatography mass spectrometry. Application to their characteriza-tion in wastewaters. J. Chromatogr. A. 1230, 117-122 (2012).

32. Matamoros, V., Jover, E. \& Bayona, J. M. Part-per-trillion determination of pharmaceuticals, pesticides, and related organic contaminants in river water by solid-phase extraction followed by comprehensive twodimensional gas chromatography time-of-flight mass spectrometry. Anal. Chem. 82, 699-706 (2010).

33. Casado, J. et al. Determination of benzotriazoles in water samples by concurrent derivatization-dispersive liquid-liquid microextraction followed by gas chromatography-mass spectrometry. J. Chromatogr. A. 1336, 1-9 (2014).

34. Liu, Y. S., Ying, G. G., Shareef, A. \& Kookana, R. S. Occurrence and removal of benzotriazoles and ultraviolet filters in a municipal wastewater treatment plant. Environ. Pollut. 165, 225-232 (2012).

35. Kiss, A. \& Fries, E. Occurrence of benzotriazoles in the rivers Main, Hengstbach, and Hegbach (Germany). Environ. Sci. Pollut. Res. Int. 16, 702-710 (2009).

36. Regueiro, J., Llompart, M., Garcia-Jares, C., Monteagudo, J. C. \& Cela, R. Ultrasound-assisted emulsificationmicroextraction of emergent contaminants and pesticides in environmental waters. J. Chromatogr. A. 1190, 2738 (2008).

37. Breedveld, G. D., Roseth, R., Sparrevik, M., Hartnik, T. \& Hem, L. J. Persistence of the de-icing additive benzotriazole at an abandoned airport. Water Air Soil Pollut. 3, 91-101 (2003).

38. Kotowska, U., Kapelewska, J., Kotowski, A. \& Pietuszewska, E. Rapid and sensitive analysis of hormones and other emerging contaminants in groundwater using ultrasound-assisted emulsification microextraction with solidification of floating organic droplet followed by GC-MS detection. Water. 11, 1638 (2019).

39. Kotowska, U., Biegańska, K. \& Isidorov, V. A. Screening of trace organic compounds in municipal wastewater by gas chromatography-mass spectrometry. Pol. J. Environ. Stud. 21, 129-138 (2012).

40. Kotowska, U., Kapelewska, J. \& Sturgulewska, J. Determination of phenols and pharmaceuticals in municipal wastewaters from Polish treatment plants by ultrasound-assisted emulsification-microextraction followed by GC-MS. Environ. Sci. Pollut. Res. 21, 660-673 (2014).

41. Spietelun, A., Marcinkowski, Å., de la Guardia, M. \& Namieśnik, J. Green aspects, developments and perspectives of liquid phase microextraction techniques. Talanta. 119, 34-45 (2014). 
42. Benson, F. R., Hartzel, L. W. \& Savell, W. L. 5,6-Dimethylbenzotriazole and its acyl derivatives. J. Am. Chem. Soc. 74, 4917-4920 (1952).

43. UCLA Institute for Digital Research \& Education, Statistical Consulting https://stats.idre.ucla.edu (2020).

44. Woźniak, M. K. et al. Development and validation of a GC-MS/MS method for the determination of 11 amphetamines and 34 synthetic cathinones in whole blood. Forensic Toxicol. 38, 42-58 (2020).

45. Weiss, S., Jakobs, J. \& Reemtsma, T. Discharge of three benzotriazole corrosion inhibitors with municipal wastewater and improvements by membrane bioreactor treatment and ozonation. Environ. Sci. Technol. 40, 7193-7199 (2006).

46. Jover, E., Matamoros, V. \& Bayona, J. Characterization of benzothiazoles, benzotriazoles and benzosulfonamides in aqueous matrixes by solid-phase extraction followed by comprehensive two-dimensional gas chromatography coupled to time-of-flight mass spectrometry. J. Chromatogr. A. 1216, 4013-4019 (2009).

47. Papageorgiou, M., Kosma, C. \& Lambropoulou, D. Seasonal occurrence, removal, mass loading and environmental risk assessment of 55 pharmaceuticals and personal care products in a municipal wastewater treatment plant in Central Greece. Sci. Total Environ. 543, 547-569 (2016).

48. Wu, Q., Lam, J. C. W., Kwok, K. Y., Tsui, M. M. P. \& Lam, P. K. S. Occurrence and fate of endogenous steroid hormones, alkylphenol ethoxylates, bisphenol A and phthalates in municipal sewage treatment systems. J. Environ. Sci. 61, 49-58 (2017).

49. Kotowska, U., Kapelewska, J. \& Sawczuk, R. Ocurrence, removal, and environmental risk of phthalates in wastewaters, landfill leachates, and groundwater in Poland. Environ. Pollut. 267, 115643 (2020).

50. Struk-Sokołowska, J. et al. Impact of differences in speciation of organic compounds in wastewater from large WWTPs on technological parameters, economic efficiency and modelling of chemically assisted primary sedimentation process. J. Environ. Chem. Eng. 8, 104405 (2020).

51. Struk-Sokołowska, J., Mielcarek, A., Wiater, J. \& Rodziewicz, J. Impacts of dairy wastewater and pre-aeration on the performance of SBR. Desalination Water Treat. 105, 41-50 (2018).

52. Struk-Sokołowska, J. Changes of COD fractions share during municipal wastewater treatment with big dairy wastewater participation. Rocznik Ochrona Środowiska. 13, 2015-2032 (2011).

53. Struk-Sokołowska, J., Rodziewicz, J. \& Mielcarek, A. Effect of dairy wastewater on changes in COD fractions in technical-scale SBR type reactors. Water Sci. Technol. 1, 156-169 (2018).

54. Rice, E. W., Baird, R. B., Eaton, A. D. \& Clesceri, L. S. Standard methods for the examination of water and wastewater. 23 nd Edition. (Ame. Pub. Hea. Ass. (APHA), Ame. Wat. Wor. Ass. (AWWA), Wat. Envir. Fed. (WEF) 2017).

55. Naccarato, A., Gionfriddo, E., Sindona, G. \& Tagarelli, A. Simultaneous determination of benzothiazoles, benzotriazoles and benzosulfonamides by solid phase microextraction-gas chromatography-triple quadrupole mass spectrometry in environmental aqueous matrices and human urine. J. Chromatogr. A. 18, 164-173 (2014).

\section{Tables}

Table 1. USAEME-GC-MS method validation parameters determined with water as sample matrix (SD - standard deviation; $r^{2}$ - coefficient of determination; CV - coefficient of variation; LoD - limit of detection; LoQ - limit of quantification; * $\times 10^{3}$ ) 


\begin{tabular}{|c|c|c|c|c|c|c|c|c|}
\hline \multirow[t]{2}{*}{ Compound } & \multicolumn{2}{|l|}{ Linearity } & \multirow[t]{2}{*}{$r^{2}$} & \multicolumn{2}{|c|}{ Recovery (\%) } & \multirow{2}{*}{$\begin{array}{l}\text { CV } \\
(\%)\end{array}$} & \multirow{2}{*}{$\begin{array}{l}\mathrm{LoD} \\
\text { (ng/L) }\end{array}$} & \multirow{2}{*}{$\begin{array}{l}\mathrm{LoQ} \\
\text { (ng/L) }\end{array}$} \\
\hline & $\begin{array}{l}\text { Slope } \\
\text { (SD)* }\end{array}$ & $\begin{array}{l}\text { Intercept } \\
(\mathrm{SD})^{*}\end{array}$ & & $\begin{array}{l}0.2 \\
\mu g / L\end{array}$ & ${ }_{\mu \mathrm{g} / \mathrm{L}}^{2}$ & & & \\
\hline BT & $402(6)$ & $12(14)$ & 0.9983 & $112 \pm 1$ & $106 \pm 5$ & 6.4 & 1.2 & 4.0 \\
\hline 4MBT & 712 (11) & $90(36)$ & 0.9960 & $108 \pm 8$ & $112 \pm 2$ & 6.5 & 0.7 & 2.3 \\
\hline 5MBT & 2616 (42) & $-378(118)$ & 0.9900 & $98 \pm 8$ & $95 \pm 2$ & 8.8 & 0.2 & 0.5 \\
\hline $\begin{array}{l}\text { 5ClBT } \\
\text { (peak1) }\end{array}$ & $281(4)$ & $17(38)$ & 0.9971 & $96 \pm 4$ & $102 \pm 2$ & 7.7 & 1.7 & 5.7 \\
\hline $\begin{array}{l}\text { 5ClBT } \\
\text { (peak2) }\end{array}$ & $272(6)$ & $80(23)$ & 0.9918 & $116 \pm 3$ & $87 \pm 7$ & 9.8 & 1.8 & 5.9 \\
\hline $5 \mathrm{CIBT}\left(\sum\right)$ & 599 (14) & $59(39)$ & 0.9954 & $108 \pm 5$ & $94 \pm 6$ & 7.7 & 0.9 & 3.0 \\
\hline UV326 & 3786 (93) & 641 (297) & 0.9999 & $81 \pm 6$ & $118 \pm 6$ & 4.7 & 0.1 & 0.4 \\
\hline UV329 & 3608 (87) & $1588(752)$ & 0.9900 & $106 \pm 7$ & $121 \pm 6$ & 6.6 & 0.1 & 0.5 \\
\hline
\end{tabular}

Table 2. Comparison of the proposed method with other approaches based on different extraction techniques and gas chromatography detection ( $L O D$ - limit of detection; *El-MS unless otherwise stated; **ionic liquid stationary phase; $* \star \star t r i p l e ~ q u a d r u p o l e)$. 


\begin{tabular}{|c|c|c|c|c|c|c|c|c|}
\hline Analytes & $\begin{array}{l}\text { Kind of } \\
\text { matrix }\end{array}$ & $\begin{array}{l}\text { Sample } \\
\text { volume } \\
\text { (mL) }\end{array}$ & Method & $\begin{array}{l}\text { Solvent } \\
\text { volume } \\
(\mathrm{mL})\end{array}$ & $\begin{array}{l}\mathrm{LODs} \\
(\mu \mathrm{g} / \mathrm{L})\end{array}$ & $\begin{array}{l}\text { Precission } \\
\text { (\%) }\end{array}$ & $\begin{array}{l}\text { Relative } \\
\text { recovery* } \\
\text { (\%) }\end{array}$ & Reference \\
\hline BT & $\begin{array}{l}\text { Airport run- } \\
\text { off }\end{array}$ & $\begin{array}{l}500- \\
1000\end{array}$ & $\begin{array}{l}\text { SPE-GC- } \\
\text { MS* }^{\star}\end{array}$ & $\begin{array}{l}\text { No } \\
\text { data }\end{array}$ & 0.1 & No data & No data & 37 \\
\hline LMBTs & River & 2500 & $\begin{array}{l}\text { SPE-GC- } \\
\text { MS }\end{array}$ & 8 & $\begin{array}{l}0.008- \\
0.012\end{array}$ & No data & $62-70$ & 35 \\
\hline LMBTs & Wastewater & 200 & $\begin{array}{l}\text { SPE-GC- } \\
M^{\star *}\end{array}$ & 25 & No data & $<10.0$ & $78-98$ & 31 \\
\hline LMBTs & $\begin{array}{l}\text { Airport run- } \\
\text { off }\end{array}$ & $\begin{array}{l}\text { No } \\
\text { data }\end{array}$ & $\begin{array}{l}\text { SPE-GC- } \\
\text { MS }\end{array}$ & 61 & $\begin{array}{l}0.0003- \\
0.01\end{array}$ & $7.2-12$ & $68-102$ & 23 \\
\hline LMBTs & $\begin{array}{l}\text { Tap, } \\
\text { groundwater, } \\
\text { effluents }\end{array}$ & 1000 & 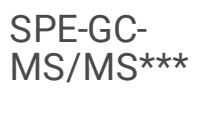 & 19 & $\begin{array}{l}0.004- \\
0.016\end{array}$ & No data & $70-122$ & 22 \\
\hline LMBTs & $\begin{array}{l}\text { Municipal } \\
\text { wastewater }\end{array}$ & 1000 & $\begin{array}{l}\text { SPE-GC- } \\
\text { MS/MS }\end{array}$ & 19 & $<0.02$ & $1.2-5.1$ & $75-133$ & 34 \\
\hline LMBTs & $\begin{array}{l}\text { Tap, surface, } \\
\text { wastewater }\end{array}$ & $1.6-8$ & $\begin{array}{l}\text { SPME-GC- } \\
\text { MS/MS }\end{array}$ & 0 & $0.2-15$ & $0.1-27.0$ & $57-117$ & 55 \\
\hline LMBTs & $\begin{array}{l}\text { River, } \\
\text { municipal } \\
\text { wastewater }\end{array}$ & $\begin{array}{l}500- \\
1000\end{array}$ & $\begin{array}{l}\text { SPE- } \\
\text { GCXGC- } \\
\text { ToF-MS }\end{array}$ & 25 & $\begin{array}{l}0.048- \\
0.112\end{array}$ & $<15.7$ & 78-115 & 46 \\
\hline LMBTs & River & 200 & $\begin{array}{l}\text { SPE- } \\
\text { GCxGC- } \\
\text { ToF-MS }\end{array}$ & 22 & $\begin{array}{l}0.006- \\
0.038\end{array}$ & $10.0-12.0$ & $66-102$ & 6 \\
\hline LMBTs & $\begin{array}{l}\text { Tap, river, } \\
\text { municipal } \\
\text { wastewater }\end{array}$ & 10 & $\begin{array}{l}\text { DLLME- } \\
\text { GC-MS }\end{array}$ & 1.6 & $\begin{array}{l}0.007- \\
0.080\end{array}$ & $<8.0$ & $92-112$ & 33 \\
\hline LMBTs & $\begin{array}{l}\text { Municipal } \\
\text { and dairy } \\
\text { wastewater }\end{array}$ & 5 & $\begin{array}{l}\text { USAME- } \\
\text { GC-MS }\end{array}$ & 0.08 & $\begin{array}{l}0.006- \\
0.035\end{array}$ & $<11.7$ & 77-137 & This work \\
\hline BUVs & $\begin{array}{l}\text { Municipal } \\
\text { wastewater }\end{array}$ & 1000 & $\begin{array}{l}\text { SPE-GC- } \\
\text { MS/MS }\end{array}$ & 19 & $\begin{array}{l}0.0015- \\
0.0056\end{array}$ & No data & $89-110$ & 22 \\
\hline BUVs & $\begin{array}{l}\text { Municipal } \\
\text { wastewater }\end{array}$ & 1000 & $\begin{array}{l}\text { SPE-GC- } \\
\text { MS/MS }\end{array}$ & 19 & $<0.0163$ & $0.5-3.8$ & $75-133$ & 34 \\
\hline BUVs & $\begin{array}{l}\text { Municipal } \\
\text { and dairy } \\
\text { wastewater }\end{array}$ & 5 & $\begin{array}{l}\text { USAME- } \\
\text { GC-MS }\end{array}$ & 0.08 & $\begin{array}{l}0.001- \\
0.005\end{array}$ & $<9.3$ & 107-124 & This work \\
\hline
\end{tabular}

Table 3. Concentration of benzotriazoles in analyzed municipal and dairy wastewater (MWWTP - municipal wastewater treatment plant; SC - sampling campaign; SBR - sequencing batch reactor; n.a.-not analyzed; *after mechanical treatment; $* \star$ after 190 minutes of aeration; ***from SBR, end of sedimentation). 


\begin{tabular}{|c|c|c|c|c|c|c|c|}
\hline \multicolumn{2}{|c|}{ Origin of wastewater samples } & \multicolumn{6}{|c|}{ Concentration $(\mu \mathrm{g} / \mathrm{L})$} \\
\hline & & BT & 4BT & 5BT & 5ClBT & UV326 & UV329 \\
\hline \multirow{5}{*}{$\begin{array}{l}\text { MWWTP A } \\
\text { SC1 }\end{array}$} & Influent & 3.46 & 0.41 & 0.06 & n.a. & n.a. & n.a. \\
\hline & Denitrification chamber & 3.21 & 0.44 & 0.7 & n.a. & n.a. & n.a. \\
\hline & Dephosphatation chamber & 3.30 & 0.10 & $<L O D$ & n.a. & n.a. & n.a. \\
\hline & Nitrification chamber & 2.28 & 0.09 & $<L O D$ & n.a. & n.a. & n.a. \\
\hline & Effluent & 2.17 & 0.11 & $<L O D$ & n.a. & n.a. & n.a. \\
\hline \multirow{2}{*}{$\begin{array}{l}\text { MWWTP A } \\
\text { SC2 }\end{array}$} & Influent & 2.58 & 0.26 & 0.12 & $<L O D$ & 0.01 & 0.01 \\
\hline & Effluent & 0.95 & 0.02 & 0.07 & $<L O D$ & $<L O D$ & $<$ LOD \\
\hline \multirow{2}{*}{$\begin{array}{l}\text { MWWTP A } \\
\text { SC3 }\end{array}$} & Influent & 0.26 & 0.26 & 0.38 & 0.06 & 0.12 & 0.15 \\
\hline & Effluent & 0.06 & 0.06 & 0.07 & 0.01 & 0.03 & 0.03 \\
\hline \multirow{2}{*}{$\begin{array}{l}\text { MWWTP A } \\
\text { SC4 }\end{array}$} & Influent & 0.21 & 0.08 & 0.05 & 0.05 & 0.17 & 0.14 \\
\hline & Effluent & 0.41 & 0.12 & 0.14 & 0.01 & 0.01 & $<\mathrm{LOD}$ \\
\hline \multirow{2}{*}{$\begin{array}{l}\text { MWWTP A } \\
\text { SC5 }\end{array}$} & Influent & 6.11 & 0.38 & 0.27 & $<L O D$ & 0.28 & 0.21 \\
\hline & Effluent & 2.18 & 0.10 & $<L O D$ & $<L O D$ & 0.08 & 0.07 \\
\hline \multirow[t]{4}{*}{ MWWTP B } & Influent & 0.61 & 5.31 & 0.07 & n.a. & n.a. & n.a. \\
\hline & Retention chamber* & 1.15 & 0.46 & 0.64 & n.a. & n.a. & n.a. \\
\hline & $\mathrm{SBR}^{\star \star}$ & 0.73 & 0.48 & 0.52 & n.a. & n.a. & n.a. \\
\hline & Effluent*** & 0.62 & 0.49 & 0.49 & n.a. & n.a. & n.a. \\
\hline \multirow[t]{2}{*}{ MPP } & Influent & $<L O D$ & 0.08 & $<L O D$ & 0.09 & 0.01 & 0.01 \\
\hline & After flotation & $<$ LOD & $<L O D$ & $<L O D$ & $<L O D$ & $<L O D$ & $<\mathrm{LOD}$ \\
\hline
\end{tabular}

\section{Figures}



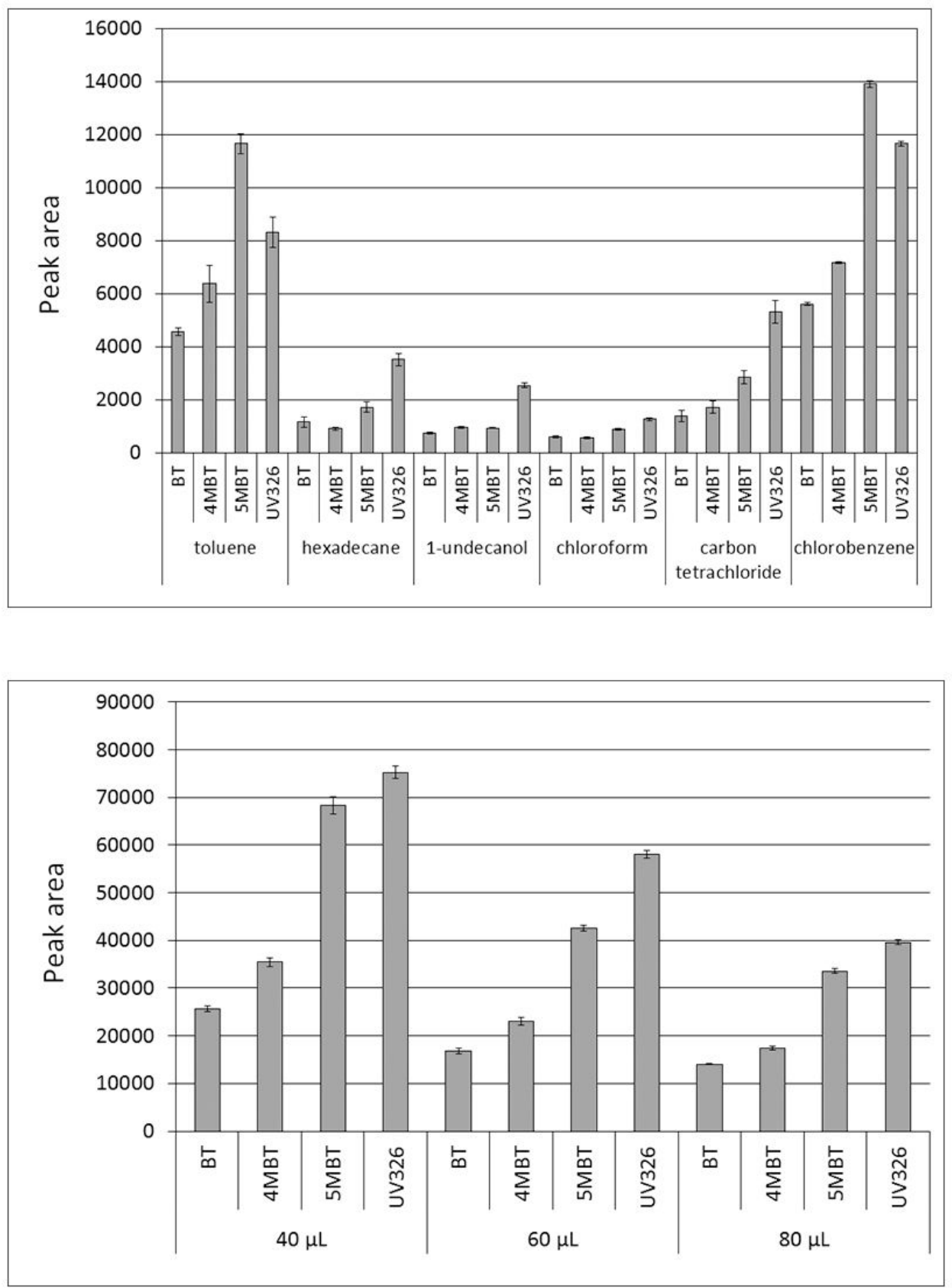

Figure 1

Influence of the type of solvent (A) and the volume of chlorobenzene (B) on the efficiency of benzotriazole extraction by the USAEME technique 

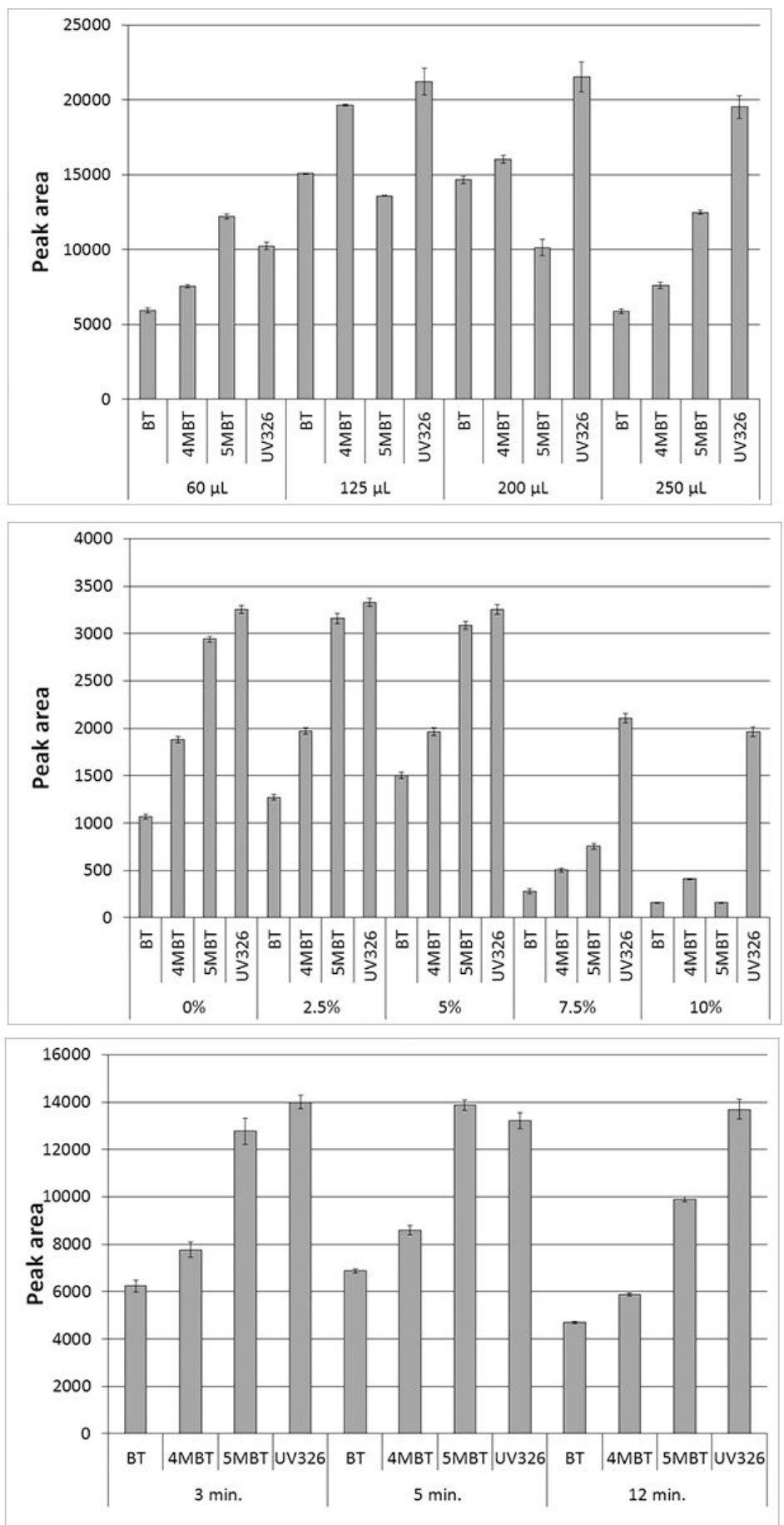

Figure 2

Influence of the acetic anhydride volume (A), ionic strength (B), and extraction time (C) on the efficiency of benzotriazole extraction by the USAEME technique 

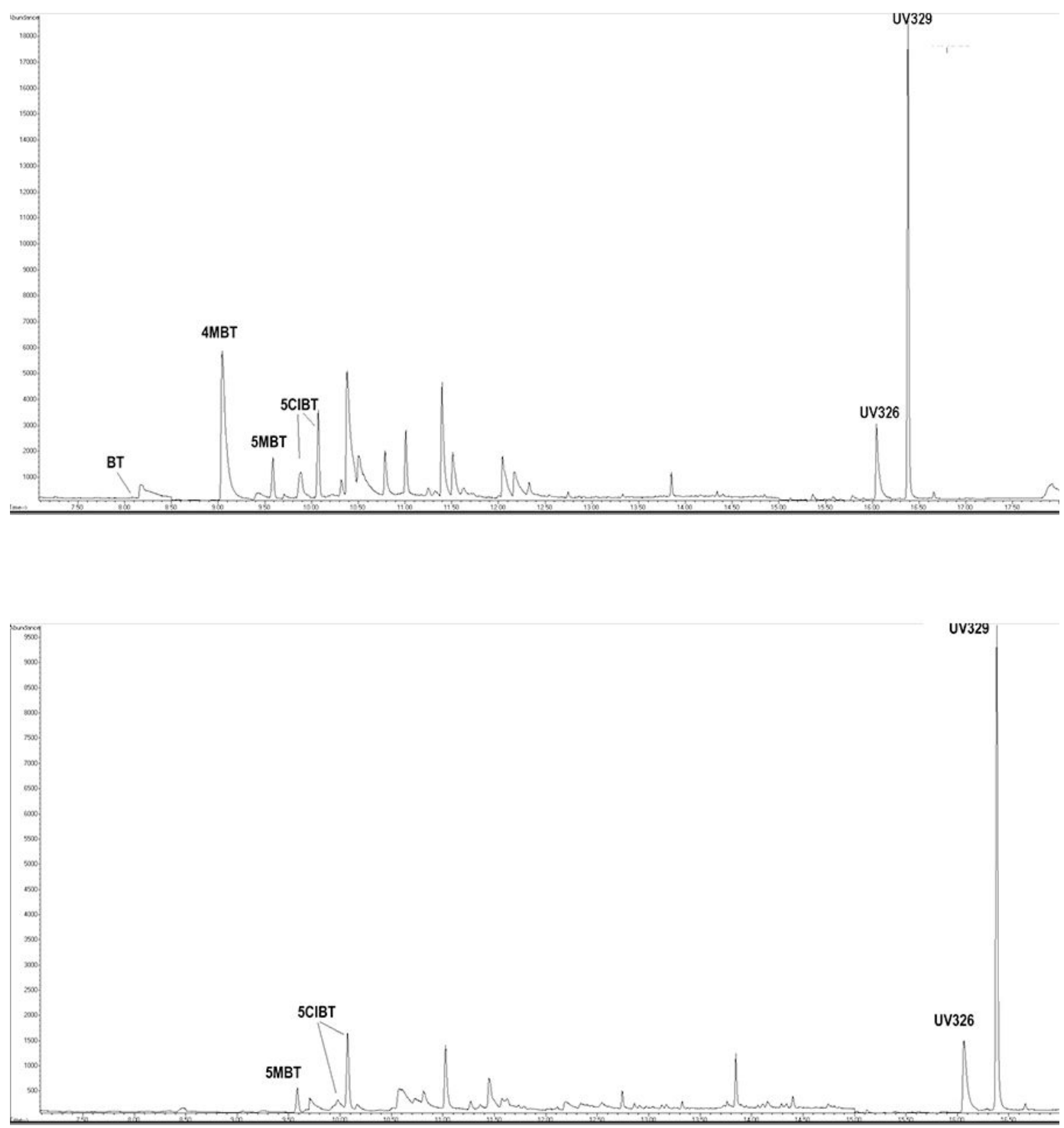

\section{Figure 3}

Chromatograms recorded for the influent (A) and effluent (B) wastewater from WWTP A 

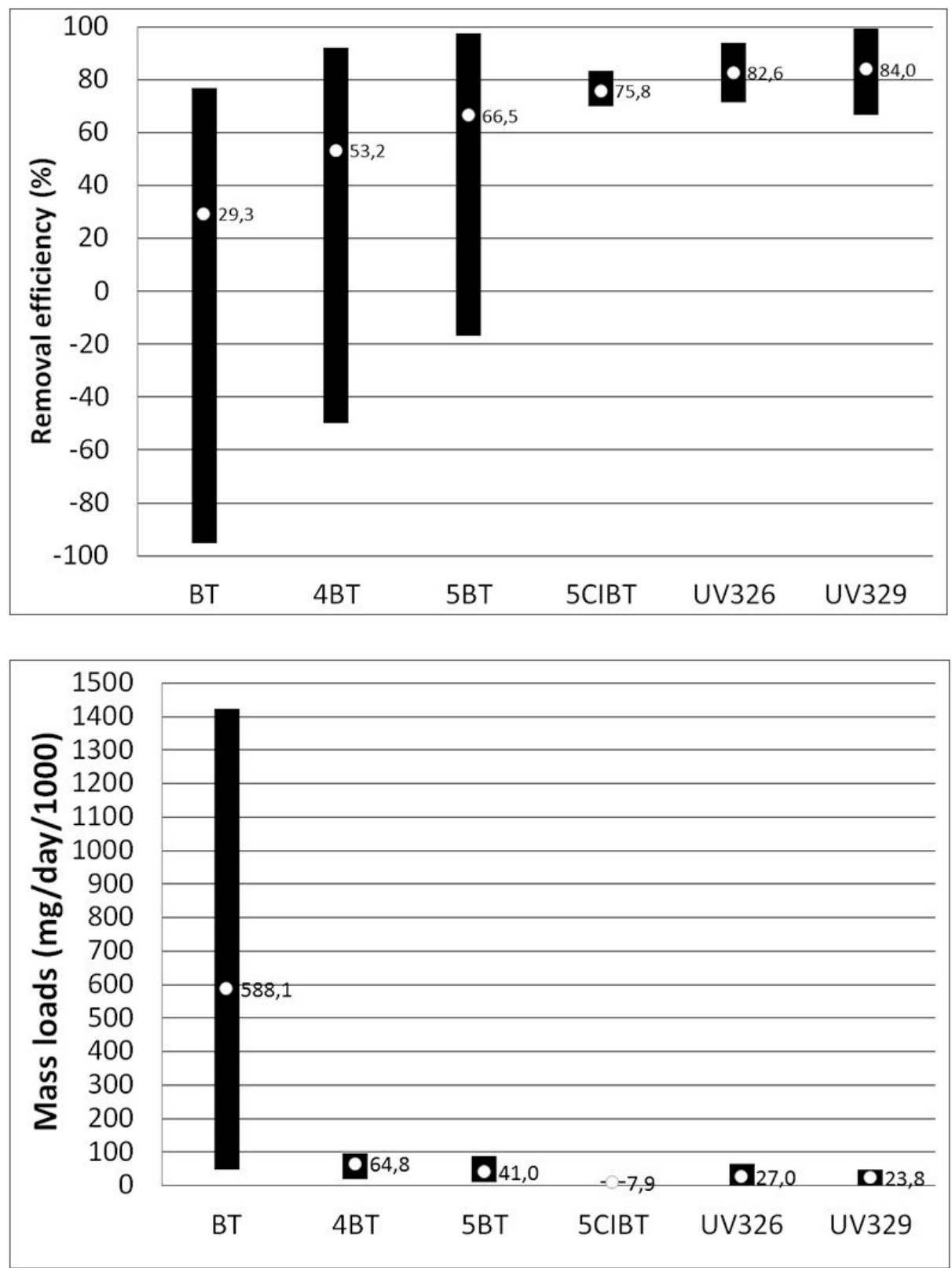

Figure 4

The range and mean mass loads of target compounds flowing with influents into WWTP (A) and introduced with effluents into the aquatic environment (B). 


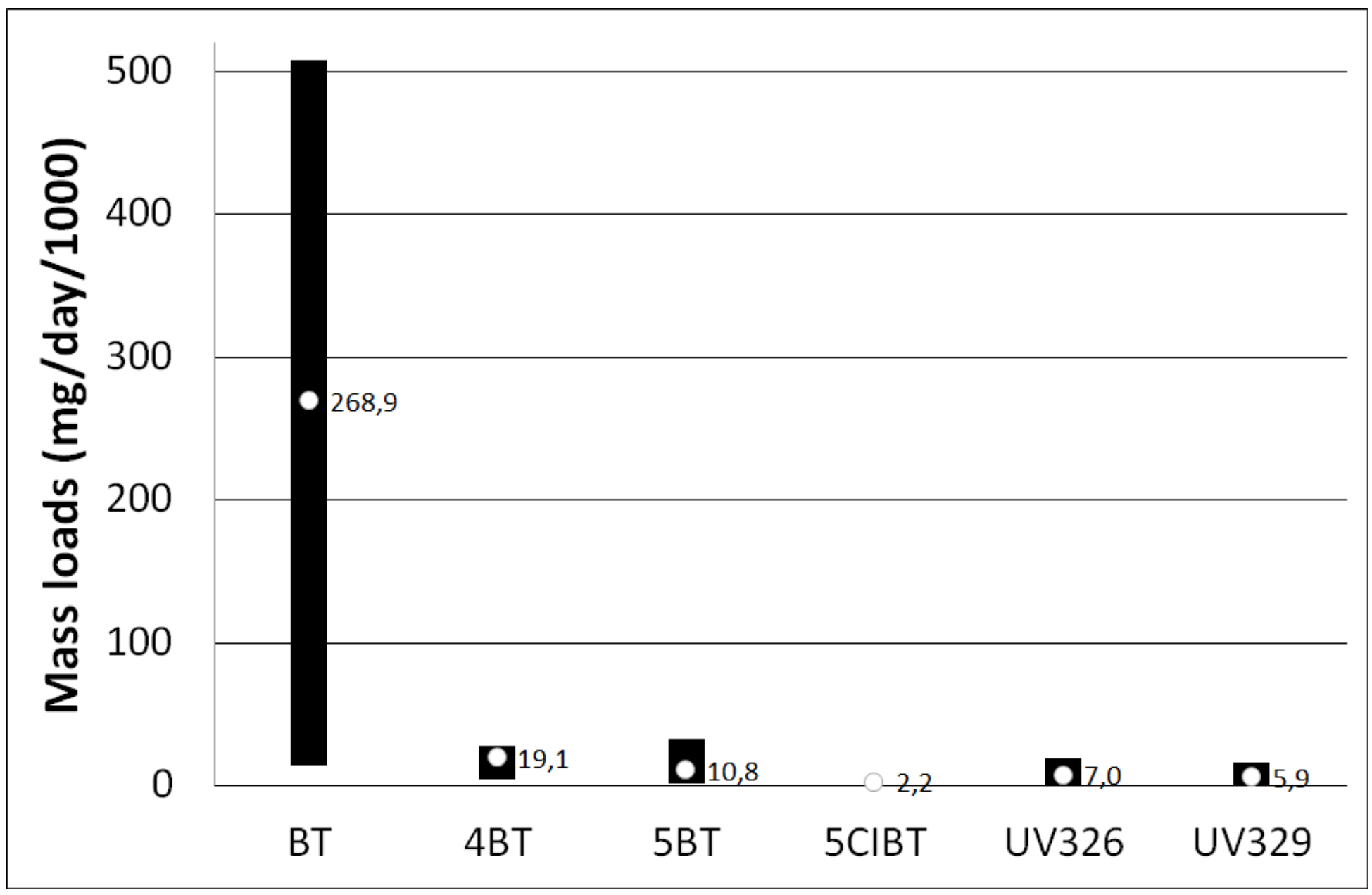

Figure 5

The range and average values of the removal efficiency of benzotriazoles in the WWTP A

\section{Supplementary Files}

This is a list of supplementary files associated with this preprint. Click to download.

- Supplementarymaterialbis.docx 